\title{
THE ILLOCUTIONARY ACTS IN THE MOVIE THE DEATH CURE: PRAGMATICS STUDY
}

\author{
Eka Nur Ariesta ${ }^{1}$, Ervina CM Simatupang ${ }^{2}$ \\ ${ }^{1,2}$ English Department, Widyatama University \\ ${ }^{1}$ ervina.simatupang@widyatama.ac.id
}

\begin{abstract}
Illocutionary act is part of speech acts which are something in order to do something as what the speaker intents. Based on Yule (1996: 48) stated that illusionary act is performed via the communicative force of utterance. Illocutionary act is a performance of act in saying something .Next, based on Vanderveken, Daniel (2009: 97) mentioned illocutionary acts of the meanings in the use and comprehension of language. The finding shows that the dialogue in the Death Cure movie contains each of illocutionary acts. The Death Cure is the third sequel that tells the story of how Thomas tried to save Minho which became the cover of the film The Maze Runner: The Scorch Trial. The film once again directed by Wes Ball is the closing film for the film The Maze Runner film version. Viewed from the context of understanding speech act has a significant or important role because the communication process will not run smoothly or well if the speaker and speech partner do not understand the context and lack of understanding of the context makes them unable to connect with each other or cannot understand each other's speech. They are representative illocutions, directives, illocutions, committees, expressives, and declarations. 2 types of strategies namely direct strategy, which has a literal meaning in the context and indirect strategy which has implicates in the context of speech, are used by speakers in uttering their speech. The data is taken from The Death Cure Movie. The method used in this thesis is the analytical descriptive-comparative method. It is used to get a clear and objective description of the Illocutionary in the movie.
\end{abstract}

Keywords: Illocutionary, directives, illocutions, expressives and pragmatics

\section{Introduction}

Pragmatics is a field of linguistics concentrating on contextual meaning as utterd by a writer and analyzed by addressee. This field requires the addressee to understand what is the speaker meaning, what is the speaker's expectation, and what is the speaker's intention by speech that words .Yule, George (1996: 3) defines pragmatics is concerned with the study of meaning as communicated by a speaker (or a writer) and interpreted by a listener (or a reader).Pragmatics are interesting because it studies how to use, people do not only analyze the meaning of utterance but also from its contextual meaning.

One of them is speech acts that are important for pragmatism. Speech acts are defined as something which is done by utterances. In this scope, when a speaker is something, it doesn't mean that something is contained nothing. There is an 
implicit meaning inside, then the address will be able to interpret what is the speaker intents. Speech acts are also divided into three types; among them are locutionary act, illocutionary act, and perlocutionary act. First, localization acts as the act of saying something with literally meaning. It means, when people say something, they say or convey the meaning of adjusting to the syntax rules. Second, illusionary act can be defined as saying something to make the addressee do something as the speaker expects. Third, the perlocutionary act is carried out by the addressee for what was said by the speaker. The difference between illocutionary act and perlocutionary act is, illocutionary act is an utterance said by the speaker in order to the addressee doing something for that, while perlocutionary is the effect caused by the utterance. For example, a lecturer said to students "this room is so hot", based on the illusion, it means that students turn on AC or fan, and it means that student turn on the $\mathrm{AC}$ or fan.

However, in this paper, the writer focuses more on the analysis of illocutionary act. Illocutionary act is not only faced in people's real life but also in the literary works, such as novels, short stories, drama, and even movies. Movie becomes an interesting source of data because it is an art work that reflects human life and is also supported by audio visual, which makes the people feel the situation in it. Considering that there is a need for a deeper understanding of illiteracy in order to interpret what is the speaker's meaning, and what the speaker's intention is, the writer is interested in analyzing the illocutionary act in "The Death Cure" movie, as there are many illocutionary acts in the dialogues of this movie. The problems of this study are formulated as below:1) What kinds of illusions are identified in The Death Cure movie? 2) What are the meanings of the illocutionary acts are interpreted in this movie?

Illocutionary act is a part of speech act which utters something in order to the addressee does something as what the speaker intents. Based on Yule (1996: 48) stated that the illocutionary act is performed via the communicative force of an utterance. Austin in Trisnawati, Garnis (2011: 236) also said that illocutionary act is performance of an act in saying something. Next, based on Vanderveken, Daniel (2009: 97) mentioned illocutionary acts are the primary units of sentence meaning in the use and comprehension of language.

Considering that it is necessary to analyze the illocutionary act in the movie in order to avoid misunderstanding in social life through what the speaker is saying in the dialogue that is available in the movie.

Furthermore, Yule (1996: 5354)) classifies the illocutionary act into five types of speech forms, among them are: 1) Representatives are the form of speech that utters what the speaker conveys about his beliefs is true, for example stating, suggesting, boasting, complaining, claiming, reporting, describing, telling, insisting, hypothesizing, asserting, and swearing, 2) Directives are the speech form that is intended to make the addressee something, for example, ordering, commanding, 
requesting, advising, recommending, online, defying, and challenging, 3) Committees are speech form, which has a function to declare the action in the future, such as promising, promoting, threatening, intending, and vowing, 4) Expressives are speech form has a function to express or state the speaker feels to a situation, for example congratulating, thanking, deploring, condoling, welcoming, apologizing, praising, pardoning, blaming, and accusing, 5) Declarations are speech forms that can change something by utterance, such as blessing, firing, resigning, baptizing, christening, naming, communicating, appointing, and sentencing.

\section{Method}

In this research, the writer used the qualitative method by observing the data in the dialogues, collecting the data which contains illocutionary acts, and then grouping them in each kinds of illocutionary act. The data was taken by the dialogues in the Death Cure movie by Wes Ball in 2018. There are various illocutionary acts with different functions.

Qualitative research is based on post positivism philosophy, because it is used to analyze natural object conditions, (as opposed to experiment) where the researcher is a key instrument, taking the data source purposively and snowball, collecting technique with triangulation (combined), data analysis is inductive / qualitative, and the results of qualitative research emphasize the meaning rather than generalization.

\section{Result and Discussion}

The finding shows that the dialogue in the Death Cure movie contains each of illocutionary acts. They are representatives (5 illocutions), directives (4 illocutions), commissives (3 illocutions), expressives (6 illocutions), and declarations (1 illocution).

a. Data 1

Thomas: "Brenda, we're coming behind .Keep 'em busy. Hang on! " (minute 00:02:41). From data 1 above, the speaker (Thomas) gives the command for his addressee, in this context, Brenda. They and the team are on a mission to save their partner, Minho. Minho at that time was being held captive by WICKED because he had a strong need for endurance which was thought to be able to break the movement of Flare virus in the patient's body. The Flare virus is a virus outbreak that can cause infected people to become zombies (Cranks). Because of the large number of people there who are infected with the virus, WICKED tries to find a cure in any way, one of which is by capturing some young people who are indicated to have strong body immunity and take their blood. For this reason, Minho (one of the young people) was arrested for taking blood. However, Minho's colleagues who had been released did not accept when Minho was used as a trial and blood drawn tool, because that could cause Minho to die. Then, they formed a team to save him.

They started their mission when Minho and the others were on their way to be moved from one place to another or called The Last City (the headquarters of the WICKED organization is located).They were 
transferred by train. At that time Brenda and Jorge were assigned to outwit WICKED's guards, while Thomas and Vince were tasked with cutting off the two back gates of the train which Minho suspected were inside. In his mission, Thomas gave orders to Brenda to continue tricking WICKED's guards by making him busy with the arrival of Brenda and Jorge.

The command sentence uttered by Thomas to Brenda is one type of illocutionary act, called directive. The directive is an action used by the speaker to ask the listener to do something he wants from expressing the sentence. Thomas contains directives because he asks Brenda to keep the enemies busy so they are not aware of Thomas and Vince's whereabouts. Thomas also added to Brenda to continue to be careful during the mission carried out. This clearly contains an element of directive, because Thomas or the speaker pronounces the sentence with the intention that Brenda or the second speaker understands and does what the speaker wants or expects.

b. Data 2

Guard " Transport zero-onenine we got trouble on the rail line.Mile 23, send backup!Send backup! ". (Minute 00:02:59).

From data 2 above, the speaker (Guard) reports the conditions that are happening on the way. At that time, the train they were riding to take the prisoners to The Last City experienced a disturbance. The disturbance came from Minho's colleagues (one of the prisoners) who intended to free Minho by attacking the train. One guard from WICKED reported the problem to a pilot who was in control of a helicopter that was indeed assigned as a backup when the train was interrupted.

Speakers in this context use a representative type of illocutionary act. Representative is one type of illocutionary act which is the speaker because in the sentence uttered, he is reporting the problems faced by the guards on the train to the pilot. He reported of course with the intention that the pilot sent reinforcements to fight Minho's colleagues.

The utterance refers to representative illocutionary act. A representative is defined as a belief speaker. In this context, the Guard reports his belief about the trouble he faces, and it is clear this utility uses reporting elements of representative. c. Data 3

Thomas "Hey Brenda, you got company! " (minute 00:04:53). The word "company" in this context is meant enemy. During the Minho rescue mission, Minho's colleagues began to press the opposing party with repeated fire attacks. The guards who guarded the prisoners were depressed and reported the problem to one of his colleagues who was in the helicopter to help them. Shortly after the report was received, the guards who were in the helicopter immediately arrived and tried to attack Minho's colleagues to stop interfering with the prisoner's transfer process .At that time Brenda and Jorge were holding a shootout with the guards who were on the train. Thomas, who saw a helicopter coming and was scouting Brenda and Jorge, quickly reported that a new enemy had arrived. Thomas suggested that Brenda and Jorge be more careful in this mission. 
From data 3 above the speaker (Thomas) gives a warning and at the same time a suggestion to his audience (Brenda) that there is an enemy approaching and he suggests that Brenda be careful. This test contains a type of directive from the illocutionary act, which when the speaker expresses something he is not just saying it. However, he hopes someone who hears it does something he wants from saying the sentence. As in this third data, Thomas tells Brenda that an enemy is coming. He does not merely say that only as information, but there is an implicit meaning in the utterance. He wanted Brenda and Jo Rge to be more careful and know what actions they should take afterwards .Besides that, this speech contained an element of advising, one of the elements in the direct illocutionary act, by suggesting Brenda and Jorge to be more alert to the enemy. For this reason, this expression belongs to the type of directive illocutionary act.

d. Data 4

Pilot " Step out of the vehicle with your hands up .Stop right there. Don't move. " (minute 00:08:24).

From data 4, the speaker (Pilot) utters the utterance with the intention that the interlocutor, in this context Brenda and other colleagues are submissive and obedient to the commands expressed by the pilot. Minho's rescued mission, Brenda and Jorge lured the guards inside the helicopter to follow him to a place where their other colleagues were hiding. The strategy is used so that Thomas and Vince can more freely cut the back gate of the train to save Minho. When Brenda and the guards arrived at a place Brenda had planned, the pilot asked Brenda and his colleagues to get out of the vehicle they were riding in and surrender themselves to WICKED. If they do not comply, then other pilots and guards will take actions that endanger Brenda and her colleagues.

The word contains elements of threats and belongs to the commissive type of illocutionary act. Commissive it is an action that will be carried out by the listener after the speech is issued by the speaker. An action that will be carried out by listeners in the future, in this context, does not mean that in the future the distance is far from the time when the speech was issued. However, the future here could be the time when the speech was issued and the listener immediately did it. In this utterance, the speaker threatens the listener not to take any action against the speaker. If the listener continues to make a movement that indicates a resistance, the speaker will not hesitate to shoot him. To note, at the time of the incident, the guards were equipped with complete firearms, so that the firearms could be fired immediately. Therefore, this utterance belongs to the type of Commissive illocutionary act, because the speaker not only says the sentence but he wants the listener to do what he wants, and there is an element of threat from the speaker against the listener if the speech is not carried out.

e. Data 5

Thomas "Vince, get up here.Now, Vince! " (Minute 00:10:36). During the Minho rescue mission, the rescue team divided the team into three, the first team was assigned to outwit the opponent, the second team cut off the rear gate that 
was likely where Minho was, and the third team was tasked to transport the two rear gates using large air transportation. However, during the cutting process, they were caught in the eye by the guards, who were then armed with complete fire. With the weapons they have, they try to thwart their actions by shooting at Thomas and Vince. At that time Thomas had managed to climb above the gate of the train, while Vince was still under while taking cover from the shots. Seeing the old Vince taking action to get to the top of the gate, Thomas suggested and at the same time ordered Vince to rise to the gate at that moment.

From data 5 above, the utterances delivered by Thomas contain elements of the direct illocutionary act, because Thomas suggested and ordered Vince to do something according to what Thomas wanted. The directive is one type of illocutionary act where the speaker conveys the ideas, ideas, or thoughts he has in the hope that the listener will do what he says. The decision taken by the listener after hearing the utterance submitted may be in the form of approval or rejection. Listeners may only obey what is suggested and ordered by the speaker is the opposite. This speech is also a direct suggestion and command spoken by the speaker to the listener. For this reason, this expression belongs to the type of direct illocutionary act, because it has two elements of directive itself, namely suggestion and commanding.

\section{f. Data 6}

Thomas "He's not here. " (minute 00:12:13). The utterances spoken by Thomas are utterances that contain implied meaning. Recalling that when delivering the speech, Thomas and Minho's rescue team were in the two back gates of the train they had managed to carry. There, they were checking whether Minho was really at the gate they had taken or not, but the results were nil. Minho is not on the second gate behind the train they took. There, Thomas felt upset and disappointed because he failed to save his colleague. Thomas expressed his sadness, regret, and disappointment by saying that Minho was not here (in the two gates of the train).

From the data above, the utterance uttered by Thomas contains an element of deploring, which is an expression where the speaker feels sad or disappointed over the situation being experienced. For this reason, this expression belongs to the type of expressive illocutionary act. Where expressive is an expression that is conveyed through utterances by the speaker, with the intention that the listener knows what he feels, and immediately does something so that what he feels immediately leaves. In this context, the utterances delivered are not just information delivery without doing anything. Here, Thomas hinted at his remorse, disappointment, and sadness through spoken utterances and he hoped that his colleagues would continue to draw up plans to save Minho despite having to go to The Last City, where Minho and the other captives were.

\section{g. Data 7}

Vince " I wish I could say our troubles are over. But we're not through this yet. WICKED is still out there. They're not giving up. (minute 00:12:45). 
The speech delivered by Vince is an expression that expresses regret for unresolved problems. At that time, those who were Minho's rescue team failed to bring Minho back with them. Those who are also people who are sought after by an organization called WICKED must hide in a place where WICKED cannot find them. At that place, Vince gathered the children they managed to save from WICKED, there he revealed what he felt and hoped for. Even though his efforts failed, they had to keep on going to a place where WICKED could not reach it, without Minho. Thomas heard about it disagreed Vince's decision to go without Minho and choose to give up going to the mission. Thomas remained in his main ambition to save Minho even though he had to go to The Last City, which means he had to meet directly with the WICKED leader.

From data 7 above, it can be concluded that the utterances delivered by Vince contain elements of hope and regret. He expressed his feelings for children who were in that place. For this reason, the speech is one type of illocutionary act, namely expressive. Expressive is a speech that involves feelings in it, the speaker expresses his feelings for a situation and hopes that the listener will do something after hearing what the speaker feels. This was also made clear by Vince's statement that WICKED was still free and would not give up until his wish materialized. Vince expressed his anxiety also through the utterance, which meant they were still in a dangerous situation if they did not immediately leave the place. This is clearly included in the expressive illocutionary act because of the elements of regret and anxiety that Vince said.

h. Data 8

Harriet "Here, drink this." (Minute 00:14:13). The speech delivered by Harriet to his colleague was an attempt to calm him after the incident took two train gates .His colleague was one of the people at the gate and meant that he was one of the people saved by Thomas's team. They were quite surprised at the incident, when they arrived at Thomas's team headquarters; Harriet approached him and offered a glass of water to drink. Harriet believes that by drinking the water, his partner will be calmer. From the data 8 above, the utterances are included in one type of illocutionary act, which is representative. Representative is an attempt by the speaker to make the listener believe things presented by the listener. As Harriet did with his colleague, he tried to make his partner want to drink water from him, which he believed could calm him. This is clearly included in the representative, because it contains an element of suggesting, where the suggesting given by Harriet is the result of his belief in the water drink which can make his partner much calmer than before.

i.data

Guard " They got 40, maybe 50 kids. We're still compiling an official count, but the pilot got a good look. He thinks it was them. " (minute $00: 15: 26$ ). The guard is reporting to the WICKED leader, Janson, about the attack carried out by Thomas's team on the way to The Last City. They reported the number of children who had been released by Thomas's 
team. Even though the results are not yet valid, the estimates are 40-50 children. The report aims for the leader to give further instructions regarding the case.

Based on the context above, the utterances delivered by the Guard belong to the kind of representative of the illocutionary act. This type is an attempt by the speaker to report what he believes. In this data, the speaker (Guard) reports a case that he believes that Thomas's team succeeded in freeing children (captives) of about 50 children. In his speech, the speaker hopes the listener will react according to what he wants. That is giving him the next instruction whether he should bring the prisoners back or not. Speakers on this data also use one of the elements in the representative, namely reporting. That is also the action of reporting what happened on the way on the train and how many prisoners were rescued.

j. Data 10

Thomas " It's okay.It's just one, so take it slow, go around him.We'll be fine." (minute 00:26:58). The situation that is happening in the data above is quite gripping since Thomas, Newt, and Fry pan were on their way to The Last City to free Minho. However, to get to the destination, they must pass through a dark place where the Cranks are. As they passed, they were only confronted by one Crank. Frypan was very frightened to go ahead and get past Crank. For this reason, Thomas tried to calm Frypan, who was driving a car, to calm down and keep trying to get past Crank. Because only one Crank tried to attack them, Thomas believed that everything would be alright; they would safely pass Crank safely. That's the suggestion given by Thomas to Frypan so that he wants to move forward.

Based on the context above, the utterances uttered by Thomas contain elements of suggesting, which is one of the elements contained in the type of representative of the illocutionary act. As is known, representative is a type of illocutionary act in which the speaker gives suggestions to the listener and tries to make him believe that what he said is true. The speaker also expects the listener to do something after hearing the utterance. These actions can be in the form of rejection or approval. But in this context, the action that will be taken by Frypan can be in the form of continuing to drive the car forward or stopping in place without doing anything. This representative wants the listener to do something according to what he expects. In this context, Thomas (the speaker) wants Frypan (listeners) to continue driving and pass the Crank calmly. For this reason, this expression belongs to the type of illocutionary act, which is representative.

\section{k. Data 11}

Jorge "I'm impressed! You guys almost lasted a whole day. ". (minute 00:30:44). Jorge was one of Thomas's colleagues who followed them (Thomas, Newt, Frypan) to The Last City. While at Cranks' place, Jorge, who was then accompanied by Brenda, saw Thomas and the other colleagues surrounded by the Cranks .Their car has been overturned because of Cranks interference. Jorge and Brenda who saw it immediately shot those (Cranks) to save their comrades. After they were disrupted by Cranks, Jorge was amazed at their 
success in surviving Cranks attack. As it is known that they have been in that place for almost one night. That seemed impossible for others, given their incomplete weaponry.

From the 11 data above, the utterances conveyed by Jorge contained an element of awe and distrust of the defense carried out by his colleagues at Cranks for almost one night. For this reason, this expression belongs to the type of illocutionary act, namely expressive. Expressive is one type of illocutionary act where in the speech, the speaker involves his feelings. As in the data above, through his speech, Jorge expressed his amazement. This is clearly included in the type of expressive, Jorge uses one of the elements in the expressive itself, namely praising. Praising is used when someone is amazed or amazed at an action carried out by his interlocutor.

1. Data 12

Thomas "I'm sorry. I didn't want to bring you guys into this. " (Minute 00:30:50). In the minute, they had managed to get out of the place where Cranks was and certainly were free from their disturbances. Arriving outside the place, Thomas expressed his apology for not including them in his mission to save Minho in The Last City. Thomas did deliberately not invite them because he did not want them to be more deeply involved in this case. However, actually they still want to participate, helping Thomas save Minho.

Based on the context, the utterances conveyed by Thomas belong to the expressive illocutionary act. Where expressive here is the utterance uttered by the speaker in which there is an element of feeling he feels. Thomas uses one of the elements in the expressive, namely apologizing. Apologizing is used when the speaker feels guilty about an action he did against his interlocutor. In this context, Thomas feels guilty about his decision not to invite Jorge and Brenda into Minho's rescue action which makes them a little disappointed. through his speech Thomas conveyed his apology to Jorge and Brenda. This is clear, that this utterance contains the expressive type of the illocutionary act.

m. Data 13

Janson "Get the guns online. " (minute 00:38:49). At that minute, a chaotic demonstration was pioneered by Crowd. Crowd here means a group of members who live outside the WICKED headquarters or commonly called exiled groups. They are not allowed to enter and even live in the WICKED headquarters. Along with the demo, Thomas and his colleagues had just arrived at the place. They were forced to be in the midst of the demonstrators, because they had not found a way to get into the WICKED headquarters. While trying to break through a large wall that restricted the territory of the WICKED headquarters and the group's residence, attack after attack was launched from WICKED. Thomas and his colleagues did not escape their observations, Thomas and his colleagues were detected in the crowd of the group. Seeing Thomas and the others there, the leader of WICKED (Janson) asks his men to be more active in launching attacks.

Based on the data above, the utterances delivered by Janson 
contain firing elements. This is included in the type of declaration of the illocutionary act. Declaration is an illocutionary which when the speaker describes his proposition, the action produced will be in harmony with the reality. With the utterance delivered by Janson to his men to attack the demonstrators using online shots, verbally changed the location of the demo which had been neatly arranged to be very messy. Because on the basis of an order from the leader automatically his men will do according to what was ordered. In his speech, intended to make his listeners do what he declared, namely attacking demonstrators using online fire. The action produced and the propositions he uttered were in harmony, it was clear that the Janson utterances were included in the declaration.

\section{Conclusion}

Understanding of literally meaning does not enough, people also understand the contextual meaning in the order to the message conveyed make sense. It means, when understanding the people who are able to know what is the speaker, who is interested, and others, it can avoid misunderstanding and make no sense. Based on the discussion on illocutionary act in The Death Cure, the movie finds that there are five kinds of acts which are applied in that movie, among them are representatives, directives, committees, expressives, and declarations. The interpretation of these various dialogues, among them are ordering, reporting, advising, threatening, recommending, firing, deploring, suggesting, praising, apologizing, stating, promising, welcoming, deploring, and challenging utterances.

\section{References}

Anggito, Albi, Johan Setiawan.2018. Qualitative research methodology .West Java: CV Jejak. Retrieved from https://books.google.co.id/book s?id = 59V8DwAAQBAJ \& printsec $=$ frontcover $\& \mathrm{dq}=$ sugiyono + method + research + qualitative $\& \mathrm{hl}=\mathrm{en} \& \mathrm{sa}=\mathrm{X}$ \& ved = 0ahUKEwiAnKP3v5zhAhUQ7 XMBHa2LCJMQ6AEILDAB $\# \mathrm{v}=$ onpage $\& \mathrm{q}=$ sugiyono $\%$ X 20\% \& 20\%\%\% 20\%

Dewi, Putu Manda Martina, et al .2017. Speech Acts Found in the Movie "Fast and Furious 7".

Pringganti, Agustina. 2013 Analysis of Speech Actions in Short Story "ILONA" by Leila S. Chudori .

Sondakh, Trisna M. M. 2014 The Act of Allocation in The Movie Change-Up by David Dobkin A Pragmatic Analysis .

Wardani, Nur Azni. 2011 An Analysis of Illocutionary Act in Prince of Persia: The Sand of the Movie.

Vanderveken, Daniel. 2009 Meaning and Speech Acts: Volume 1, Principles of Language Use .Retrieved from https://books.google.co.id/book s? id = JzUL0f1jzOMC \& pg = PA103 \& dq = illocutionary + acts $\& \mathrm{hl}=\mathrm{id} \& \mathrm{sa}=\mathrm{X} \&$ ved $=$ 0ahUKEwjvnOepop3hAhXLq 
o8KHWPpAMwQ6AEIPzAD $\# \mathrm{v}=$ onepage \& $\mathrm{q}=$ illocutionary\% 20acts \& $\mathrm{f}=$ false

Yule, George. 1996. Pragmatics .Oxford University Press.

Budiman, Achmad Rosadi, Emalia Iragiliati. Illocutionary Act Seen In Barrack Obama's Speech .
Petriandy, Dolla, Vania Leni Marlina. Illocutionary Acts Found in Novel of the Never Girls: Before the Bell by Kiki Thorpe .Volume 7. Number 1

Ramayanti, Dilla, Leni Marlina. The Analysis Of Types Illocutionary Acts In "Tangled" Movie .Volume 7. Number 1 